\title{
Is miR-29 an Oncogene or Tumor Suppressor in CLL?
}

\author{
Yuri Pekarsky and Carlo M. Croce \\ Human Cancer Genetics Program and Department of Molecular Virology, Immunology and Medical Genetics, OSU School of \\ Medicine, Ohio State University, Columbus, Ohio
}

Correspondence to: Yuri Pekarsky, e-mail: Pekarsky.Yuri@osumc.edu

Received: June 9, 2010, Accepted: July 11, 2010, Published: July 16, 2010

ABSTRACT:

\begin{abstract}
B-cell chronic lymphocytic leukemia (CLL) is the most common leukemia in the Western world. CLL occurs in two forms, aggressive and indolent. Aggressive CLL is characterized by high ZAP-70 expression and unmutated IgH $\mathrm{V}_{\mathrm{H}}$; indolent CLL shows low ZAP-70 expression and mutated $\mathrm{IgH} \mathrm{V}_{\mathrm{H}}$. We recently found that miR-29 is upregulated in indolent human B-CLL, compared to aggressive B-CLL and normal CD19 ${ }^{+}$ B-cells. To determine the role of miR-29 in CLL, we generated transgenic mice overexpressing miR-29 in mouse B-cells. Recently we reported that miR-29 transgenic mice develop indolent CLL phenotype. Interestingly, our previous findings suggest that miR-29 targets expression of TCL1, a critical oncogene in aggressive CLL, indicating that miR-29 might function as a tumor suppressor in CLL. Here we discuss these results and provide additional insights into function of $m i R-29$ in CLL.
\end{abstract}

Chronic lymphocytic leukemia (CLL) is the most common human leukemia, accounting for $\sim 10,000$ new cases diagnosed each year in the United States ( $30 \%$ of all leukemia cases) [1]. CLL is mostly a disease of elderly people, with the incidence increasing linearly with each decade $[1,2]$. This disease occurs in two forms, aggressive and indolent, both forms are is characterized by the clonal expansion of CD5 positive B-cells [1,2]. Aggressive CLL is characterized by high ZAP-70 expression and unmutated $\operatorname{IgH} \mathrm{V}_{\mathrm{H}}$; indolent CLL shows low ZAP-70 expression and mutated IgH $\mathrm{V}_{\mathrm{H}}[1,2]$.

MicroRNAs are endogenous non-coding RNAs 1925 nucleotides in size [3]. Recent studies have shown that microRNAs play important roles in various cellular processes including DNA methylation [4], cellular growth, differentiation and apoptosis [5]. Recent studies revealed that nearly half of human microRNAs are located within fragile sites and genomic regions altered in various cancers [6]. Numerous reports demonstrated that, as protein coding genes, microRNAs differentially express in a number of cancers, indicating that individual microRNAs could play tumor suppressor or oncogenenic roles in cancer pathogenesis [7].

Several recent studies demonstrated that microRNA expression profiles can be used to distinguish normal B-cells from malignant CLL cells and that microRNA signatures are associated with prognosis and progression of CLL $[6,8]$. Specifically, a signature profile was reported, describing 13 microRNAs that differentiate aggressive and indolent CLL [6].

Tcl1 is a critical molecule in the pathogenesis of CLL [9]. Mouse model studies conclusively demonstrated that deregulation of TCL1 is initiating event in the development of the aggressive form of CLL $[10,11]$, in fact recent studies showed that Tcl1driven mouse CLL closely resembles the aggressive form of human B-CLL and the analysis for $\mathrm{V}_{\mathrm{H}}$ mutations showed that all the CLLs in transgenic mice carried unmutated $\mathrm{V}_{\mathrm{H}}$ genes in accordance with the aggressive phenotype [12]. We, and others, reported that the aggressive form of human B-CLL shows the highest Tcl1 expression levels $[13,14]$. Several years ago we investigated whether microRNAs regulate $T C L 1$ expression in CLL. We demonstrated that miR29 and miR-181 target TCL1 expression in CLL [14]. Interestingly, of the four down-regulated microRNAs in aggressive CLL versus indolent B-CLL, three are different isoforms of $m i R-29$ ( $m i R-29 a-2, m i R-29 b-2$ and $m i R-29 c$ ) [6], strongly suggesting that $m i R-29$ and TCL1 interactions play an important role in the pathogenesis of aggressive CLL [14]. The fact that miR-29 targets expression of $T C L 1$, a critical oncogene in aggressive CLL, indicates that miR-29 might function as a tumor suppressor in CLL. 
As noted above, we have previously reported that miR-29 expression is down-regulated in aggressive versus indolent CLL $[8,14]$, but these reports did not examine miR-29 expression in CLL versus normal CD19+ B-cells. In our latest publication in PNAS we examined expression of $m i R-29 a$ and $m i R-29 b$ in 29 aggressive CLL samples, 33 indolent CLL samples and two normal CD19+ B-cell controls [15]. We found that $m i R-29 a$ and $m i R-29 b$ expression was 4-4.5 fold higher in indolent CLL, when compared with normal CD19+ B-cells [15]. Table 1 shows summary of miR29 expression in CLL from three studies. Deletion of chromosome 11 in CLL usually indicates most aggressive phenotype. Interestingly, CLL samples showing this particular deletion express lowest levels of $m i R-29$. These data clearly indicate that $m i R-29 a$ and $m i R-29 b$ expression is clearly down-regulated in aggressive CLL versus indolent CLL.

Although deregulation of a specific gene in a certain type of cancer suggests a potential involvement in the malignancy, the final proof of the involvement of this gene in the pathogenesis of this disease requires generation of animal models showing the same malignant phenotype. To elucidate the role of miR-29 in B-cell leukemias we generated transgenic mice overexpressing miR-29 in B-cells. Very recently we reported the phenotype of this mouse model [15].

Immunophenotypic profile of spleen lymphocytes from $m i R-29$ transgenics showed increased populations of CD5+CD19+IgM+ B-cells, a characteristic of CLL. At the age of 12-24 months markedly expanded $\mathrm{CD}^{+}$ B-cell population was evident in spleens of 34 of 40
(85\%) miR-29 transgenic mice; $~ 50 \%$ of B-cells in these transgenics were $\mathrm{CD} 5$ positive [15]. Interestingly, of 20 miR-29 transgenic mice followed to 24-26 months of age, only 4 (20\%) developed frank leukemia and died of the disease. Because almost all miR-29 transgenics showed expanded CD5+CD19+IgM+ Bcell populations, but only $20 \%$ develop frank leukemia we concluded that miR-29 transgenics develop a disease similar to indolent CLL [15]. In addition, miR29 mice showed significant increases in \% of leukemic cells with age. In mice younger than 15 months, CD5+ leukemic cells represented only $\sim 20 \%$ of total B-cells; in contrast, at the age of 20-26 months, on average, $>65 \%$ of all B-cells were CD5+. These results show gradual progression of indolent B-CLL in $m i R-29$ transgenics [15]. To determine whether leukemic cells from miR-29 mice divide, we measured the proliferative capacity of $\mathrm{CD} 5+$ leukemic B-cells in comparison with WT CD19+ splenic lymphocytes. BrdU incorporation experiments showed significant proliferation in miR-29 transgenic B-cells, while no proliferation was detected for CD19+ WT lymphocytes [15]. These data suggest that miR-29 over-expression plays an important role in promoting B-cell proliferation. Since progressive hypogammaglobulinemia and immune incompetence are important features of human CLL [16], we analyzed serum levels of immunoglobulins and the immune response to SRBC antigen in the serum of $m i R-29$ transgenics and wild type siblings. We found that in $m i R-29$ transgenics immune response to SRBC antigen and serum levels of immunoglobulins were significantly decreased [15].

Table 1 Mir-29 expression in CLL

\begin{tabular}{|c|c|c|c|}
\hline $\begin{array}{c}\text { Study } \\
\text { ref. }\end{array}$ & Number of samples & Method & Results \\
\hline [8] & $\begin{array}{l}\text { Aggressive CLL } \\
\text { Indolent CLL }\end{array}$ & Microchip & $\begin{array}{l}m i R-29 a \text { and } m i R-29 b \text { down-regulated in } \\
\text { aggressive CLL vs.indolent CLL }\end{array}$ \\
\hline [14] & $\begin{array}{l}\text { Aggressive CLL } \\
\text { Aggr. CLL (Del. Chr. 11) } \\
\text { Indolent CLL }\end{array}$ & Microchip & $\begin{array}{l}m i R-29 a \text { and } m i R-29 b \text { down-regulated in } \\
\text { aggressive CLL (Del. Chr 11) vs.indolent CLL } \\
(\sim 2 \text { fold) } \\
\text { miR-29b down-regulated in aggressive CLL vs. } \\
\text { indolent CLL }(\sim 2 \text { fold })\end{array}$ \\
\hline [15] & $\begin{array}{l}\text { Aggressive CLL } \\
\text { Indolent CLL } \\
\text { Normal cord blood B-cells }\end{array}$ & $\begin{array}{l}\text { Real Time } \\
\text { RT-PCR }\end{array}$ & $\begin{array}{l}\text { miR-29a down-regulated in aggressive CLL vs. } \\
\text { indolent CLL }(\sim 1.5 \text { fold }) \\
\text { miR-29a and miR-29b up-regulated in aggressive } \\
\text { CLL vs. normal B-cells }(\sim 3 \text { fold }) \\
m i R-29 a \text { and miR-29b up-regulated in indolent } \\
\text { CLL vs. normal B-cells ( } \sim 4-5 \text { fold })\end{array}$ \\
\hline
\end{tabular}


These data confirmed our initial observations that $m i R$ 29 transgenic mice develop disease that mimics indolent human CLL.

Previously we reported that $m i R-29$ is one of two microRNAs targeting TCL1, a very important oncogene involved in the pathogenesis of aggressive CLL [14]. We also showed that TCL1 and miR-29 expression levels are inversely correlated in CLL, and that $m i R-29$ expression is down-regulated in aggressive CLL versus indolent CLL [14]. These data suggest possible tumor suppressor function for miR-29 in CLL. Very recently we reported that $m i R-29$ is up-regulated in indolent CLL compared to normal B-cells [15]. We also found that miR-29 transgenic mice showed expanded $\mathrm{CD} 5+\mathrm{CD} 19+\mathrm{IgM}+\mathrm{B}-\mathrm{cell}$ populations and develop a disease very similar to indolent human CLL [15]. This implies that up-regulation of $m i R-29$ initiates or at least significantly contributes to the pathogenesis of indolent CLL and can function as an oncogene. How can we reconcile these differences? Figure 1 shows our current view of the function of $m i R-29$ in CLL. Since TCL1 is mostly not expressed in indolent CLL [14], it likely does not play an important role in indolent CLL. Thus its down-regulation due to miR-29 overexpression does not slow indolent CLL development. We believe that up-regulation of miR-29 expression is not sufficient to cause aggressive CLL. In contrast, up-regulation of Tcll is absolutely required for the initiation of the aggressive form of CLL. In the other hand, down-regulation of miR-29 expression in aggressive CLL (compared to the indolent form) contributes to up-regulation of Tcl1 and development of aggressive CLL.

Since in all human B-CLL samples miR-29a expression levels were $>20$-fold higher compared to $m i R-29 b$ [15] and both microRNAs share the same seed sequence, it is likely that most of effects of

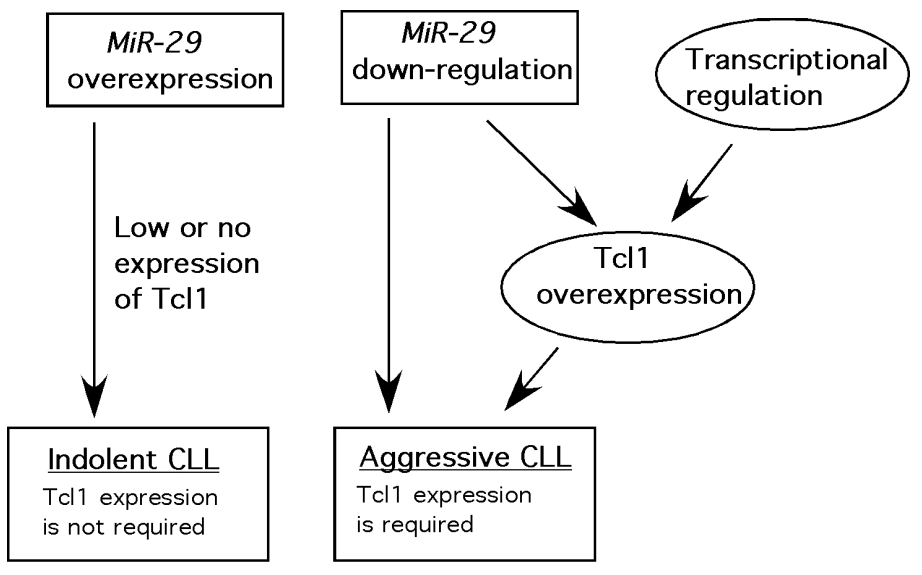

expression of miR-29ab cluster in CLL can be attributed to miR-29a. MiR-29 functions as an oncogene in B-cells by regulating its targets. Targetscan software predicts over 800 targets for $m i R$ 29 . This list contains multiple oncogenes and tumor suppressor genes. Previous reports showed that miR-29 can target TCL1, MCL1 and CDK6 oncogenes $[14,17,18]$; we propose that $m i R-29$ targets possible tumor suppressor peroxidasin [15]. Clearly, interactions of $m i R-29$ with these genes contribute to its function, but it is very likely that hundreds of unknown interactions of $m i R-29$ with its targets hold keys to its oncogenic role in CLL.

MicroRNA expression profiles were extensively studied in a number of hematological malignancies as well as in solid tumors [7]. These studies resulted in identification of several microRNAs that might function as tumor suppressors or oncogenes [7]. However, there have been only two reports demonstrating that dysregulation of a single microRNA (or a cluster) can cause cancer. The first such study defined an initiation role of miR-155 in B-cell acute leukemias [19]. Another study demonstrated that knockout of miR-15/16 led to the development of indolent B-cell malignancies [20,21]. In both cases previously published reports identified miR-155 as an oncogene and $m i R-15 / 16$ as a tumor suppressor. In contrast, there has not been a clear consensus regarding the function of $m i R-29$ in this respect. Previous studies showed that miR-29 expression was down-regulated and correlated with poor prognosis in mantle cell lymphoma [22], its re-expression caused apoptosis AML cells [17] and suppressed tumorigenicity in lung cancer cells [23]. On the other hand, in addition to our report [15], dysregulation of miR-29 expression in myeloid cells was found to cause AML in a mouse model [24], and its overexpression was reported in metastatic breast cancer [25]. Thus, it is apparent that depending on cellular contexts $m i R-29$ can function as an oncogene or a tumor suppressor.

\section{REFERENCES}

1. Sgambati M, Linet M, Devesa S (2001). Chronic Lymphocytic Leukemia, Epidemiological, Familial, and Genetic Aspects. In Chronic Lymphocytic Leukemias, Second Edition, Revised and Expanded, Cheson B, ed. (Marcel Dekker, Inc New York), pp 33-62.

2. Bullrich F, Croce C (2001). Molecular Biology of Chronic Lymphocytic Leukemia. Chronic Lymphocytic Leukemias, Second Edition, Revised and Expanded,

Fig. 1 Role of $m i R-29$ in CLL. 
Cheson B, ed. (Marcel Dekker, Inc New York), pp 932.

3. Bartel DP. MicroRNAs: genomics, biogenesis, mechanism, and function. Cell 116: 281-297.

4. Fabbri M, Ivan M, Cimmino A, Negrini M, Calin GA. Regulatory mechanisms of microRNAs involvement in cancer. Expert Opin Biol Ther 2007; 7: 1009-1019.

5. Zhang $\mathrm{H}$, Chen $\mathrm{Y}$. New insight into the role of miRNAs in leukemia. Sci China C Life Sci. 2009; 52: 224-231.

6. Calin GA, Liu CG, Sevignani C, Ferracin M, Felli N, Dumitru CD, Shimizu M, Cimmino A, Zupo S, Dono M, Dell'Aquila ML, Alder H, Rassenti L, Kipps TJ, et al. MicroRNA profiling reveals distinct signatures in B cell chronic lymphocytic leukemias. Proc Natl Acad Sci USA 2004; 101: 11755-11760.

7. Volinia S, Calin GA, Liu CG, Ambs S, Cimmino A, Petrocca F, Visone R, Iorio M, Roldo C, Ferracin M, Prueitt RL, Yanaihara N, Lanza G, Scarpa A, et al. A microRNA expression signature of human solid tumors defines cancer gene targets. Proc Natl Acad Sci USA 2006; 103: 2257-2261.

8. Calin GA, Ferracin M, Cimmino A, Di Leva G, Shimizu M, Wojcik SE, Iorio MV, Visone R, Sever NI, Fabbri M, Iuliano R, Palumbo T, Pichiorri F, Roldo C, et al. A MicroRNA signature associated with prognosis and progression in chronic lymphocytic leukemia. N Engl J Med 2005; 353: 1793-1801.

9. Pekarsky Y, Palamarchuk A, Maximov V, Efanov A, Nazaryan N, Santanam U, Rassenti L, Kipps T, Croce $\mathrm{CM}$. Tcll functions as a transcriptional regulator and is directly involved in the pathogenesis of CLL. Proc Natl Acad Sci USA 2008; 105: 19643-19648.

10. Bichi R, Shinton SA, Martin ES, Koval A, Calin GA, Cesari R, Russo G, Hardy RR, Croce CM. Human chronic lymphocytic leukemia modeled in mouse by targeted TCL1 expression. Proc Natl Acad Sci USA 2002; 99: 6955-6960.

11. Zanesi N, Aqeilan R, Drusco A, Kaou M, Sevignani C, Costinean S, Bortesi L, La Rocca G, Koldovsky P, Volinia S, Mancini R, Calin G, Scott CP, Pekarsky Y, et al. Effect of Rapamycin on Mouse Chronic Lymphocytic Leukemia and the Development of Nonhematopoietic Malignancies in Em-TCL1 Transgenic Mice. Cancer Res 2006; 66: 915-920.

12. Yan XJ, Yan XJ, Albesiano E, Zanesi N, Yancopoulos S, Sawyer A, Romano E, Petlickovski A, Efremov DG, Croce CM, Chiorazzi N. B cell receptors in TCL1 transgenic mice resemble those of aggressive, treatmentresistant human chronic lymphocytic leukemia. Proc Natl Acad Sci USA 2006; 103: 11713-11718.

13. Herling M, Patel KA, Khalili J, Schlette E, Kobayashi R, Medeiros LJ, Jones D. TCL1 shows a regulated expression pattern in chronic lymphocytic leukemia that correlates with molecular subtypes and proliferative state. Leukemia 2996; 20: 280-285.

14. Pekarsky Y, Santanam U, Cimmino A, Palamarchuk A, Efanov A, Maximov V, Volinia S, Alder H, Liu CG,
Rassenti L, Calin GA, Hagan JP, Kipps T, Croce CM. Tcl1 expression in chronic lymphocytic leukemia is regulated by miR-29 and miR-181. Cancer Res 2006; 66: 11590-11593.

15. Santanam U, Zanesi N, Efanov A, Costinean S, Palamarchuk A, Hagan JP, Volinia S, Alder H, Rassenti L, Kipps T, Croce CM, Pekarsky Y. Chronic lymphocytic leukemia modeled in mouse by targeted miR-29 expression. Proc Natl Acad Sci USA 2010; 107:12210-12215.

16. Caligaris-Cappio F, Hamblin TJ. B-cell chronic lymphocytic leukemia: a bird of a different feather. J Clin Oncol 1999; 17: 399-408.

17. Garzon R, Heaphy CE, Havelange V, Fabbri M, Volinia S, Tsao T, Zanesi N, Kornblau SM, Marcucci G, Calin GA, Andreeff M, Croce CM. MicroRNA 29b functions in acute myeloid leukemia. Blood 2009; 114: 53315341.

18. Mott JL, Kobayashi S, Bronk SF, Gores GJ. Mir-29 regulates Mcl-1 protein expression and apoptosis. Oncogene 2007; 26: 6133-6140.

19. Costinean S, Zanesi N, Pekarsky Y, Tili E, Volinia S, Heerema N, Croce CM. Pre-B cell proliferation and lymphoblastic leukemia/high-grade lymphoma in EmmiR155 transgenic mice. Proc Natl Acad Sci USA 2006; 103: 7024-7029.

20. Klein U, Lia M, Crespo M, Siegel R, Shen Q, Mo T, Ambesi-Impiombato A, Califano A, Migliazza A, Bhagat G, Dalla-Favera R. The DLEU2/miR-15a/16-1 cluster controls B cell proliferation and its deletion leads to chronic lymphocytic leukemia. Cancer Cell 2010; 17: $28-40$.

21. Zanesi N, Pekarsky Y, Trapasso F, Calin G, Croce CM. MicroRNAs in mouse models of lymphoid malignancies. J Nucleic Acids Invest 2010; 1:36-40.

22. Zhao JJ, Lin J, Lwin T, Yang H, Guo J, Kong W, Dessureault S, Moscinski LC, Rezania D, Dalton WS, Sotomayor E, Tao J, Cheng JQ. MicroRNA expression profile and identification of miR-29 as a prognostic marker and pathogenetic factor by targeting CDK6 in mantle cell lymphoma. Blood 2010; 115: 2630-2639.

23. Fabbri M, Garzon R, Cimmino A, Liu Z, Zanesi N, Callegari E, Liu S, Alder H, Costinean S, FernandezCymering C, Volinia S, Guler G, Morrison CD, Chan KK, et al. MicroRNA-29 family reverts aberrant methylation in lung cancer by targeting DNA methyltransferases 3A and 3B. Proc Natl Acad Sci USA 2007; 104: 15805-10.

24. Han YC, Park CY, Bhagat G, Zhang J, Wang Y, Fan JB, Liu M, Zou Y, Weissman IL, Gu H. MicroRNA-29a induces aberrant self-renewal capacity in hematopoietic progenitors, biased myeloid development, and acute myeloid leukemia. J Exp Med 2010; 207: 475-489.

25. Gebeshuber CA, Zatloukal K, Martinez J. MiR-29a suppresses tristetraprolin, which is a regulator of epithelial polarity and metastasis. EMBO Rep 2009; 10: 400-405. 